\title{
MRI strain analysis as a novel modality for the assessment of myocardial function following stem cell therapy-results from Amorcyte trial
}

\author{
Sabha Bhatti ${ }^{1 *}$, Abdul Hakeem ${ }^{1}$, Michael Taylor ${ }^{2}$, Eugene Chung $^{3}$, Arshed A Quyyumi ${ }^{4}$, John Oshinski ${ }^{4}$, \\ Andrew L Pecora ${ }^{5}$, Dean Kereiakes ${ }^{3}$, Kan Hor ${ }^{2}$, Wojciech Mazur ${ }^{3}$
}

From 2011 SCMR/Euro CMR Joint Scientific Sessions

Nice, France. 3-6 February 2011

\section{Objective}

To evaluate MRI strain analysis for the assessment of myocardial function following stem cell therapy.

\section{Background}

MRI strain analysis is a novel way to assess myocardial function and may detect subtle improvements in myocardial function earlier than commonly used methods of myocardial function assessment. Stem cell therapy offers a promising approach to the regeneration of damaged vascular and cardiac tissue after myocardial infarction. Myocardial strain imaging has not been evaluated as an end point in stem cell studies. Our objective was to demonstrate the role and feasibility of MRI strain analysis for the early detection of myocardial functional improvement following stem cell therapy.

\section{Methods}

The Amorcyte trial randomized 31 patients to an autologous stem cell harvest group (cells were harvested from the patient's own bone marrow) or control group five days after an ST elevation myocardial infarction (87\% Anterior). This is the the first randomized study to prospectively define a dose of a purified and potent autologous stem cell therapy that resulted in a significant improvement in perfusion, a trend towards improved EF $(+4 \%$ versus $+1 \%)$. Using the TomTec research arena MRI software $\odot$, circumferential strain was measured in short axis views at base, mid and apex for each patient at baseline, 3 and 6 months.

\section{Results}

Thirteen patients in the treatment and 11 controls were available for strain analysis. There was no significant difference in the two groups with respect to baseline characteristics including age $52+8$ vs. $53+10.5(\mathrm{p}=0.7)$, gender, race, mean ejection fraction, NYHA class, hypertension and revascularization. Mean apical circumferential strain at baseline was $-17.2(95 \% \mathrm{CI}-22.2,-12.1)$ and increased to $-20.6(95 \% \mathrm{CI}-26.7,-14.5)$ at 6 months $(\mathrm{p}=0.03)$.Mid anterior circumferential strain showed a strong trend to improvement between baseline -17(95\% CI $-23.6,-10.4)$ and 3 months $-20.49(95 \%$ CI $-25,-15.7)$ $\mathrm{p}=0.05$. There was no significant change in the base at 3 month and 6 months compared to baseline for other segments. Comparatively, no significant change was noted in segmental circumferential strain in the control group.

\section{Conclusions}

Despite a small patient population in whom traditional methods of cardiac function only showed a trend toward improvement with stem cell therapy, MRI was able to demonstrate a significant increment in circumferential strain in the apex and mid anterior segments. Larger studies evaluating MRI derived strain analysis as an endpoint following stem cell therapy including correlation with clinical endpoints are warranted.

\footnotetext{
Author details

${ }^{1}$ University of Cincinnati Hospital, Cincinnati, OH, USA. ${ }^{2}$ Cincinnati Childrens Hospital, Cincinnati, OH, USA. ${ }^{3}$ The Christ Hospital, Cincinnati, OH, USA. ${ }^{4}$ Emory University, Atlanta, GA, USA. ${ }^{5}$ Amorcyte Inc, Hackensack, NJ, USA.
}

University of Cincinnati Hospital, Cincinnati, OH, USA

Full list of author information is available at the end of the article

(c) 2011 Bhatti et al; licensee BioMed Central Ltd. This is an open access article distributed under the terms of the Creative Commons Attribution License (http://creativecommons.org/licenses/by/2.0), which permits unrestricted use, distribution, and reproduction in any medium, provided the original work is properly cited. 
doi:10.1186/1532-429X-13-S1-P86

Cite this article as: Bhatti et al:: MRI strain analysis as a novel modality

for the assessment of myocardial function following stem cell therapy-

results from Amorcyte trial. Journal of Cardiovascular Magnetic Resonance

2011 13(Suppl 1):P86

Submit your next manuscript to BioMed Central and take full advantage of:

- Convenient online submission

- Thorough peer review

- No space constraints or color figure charges

- Immediate publication on acceptance

- Inclusion in PubMed, CAS, Scopus and Google Scholar

- Research which is freely available for redistribution 